\title{
The Electoral Power of Japanese Interest Groups: An Organizational Perspective
}

\author{
Patricia L. Maclachlan
}

\begin{abstract}
What explains the electoral staying power of many Japanese interest groups in the wake of electoral reform? Electoral explanations provide part of the answer; candidates in elections to both houses of the Diet continue to face incentives-many of them unintended-to court the organized vote. But missing from such accounts is an explanation of why economically noncompetitive groups provide the bulk of such support. The primary reason for this, I argue, is organization. As a result of their historical linkages to the bureaucracy, many interests developed hierarchical, national organizational structures that enabled them to carry out a variety of vote-gathering functions that the parties had trouble performing themselves. Although electoral reform and long-term demographic trends have weakened the electoral influence of interest groups, these organizational complementarities between groups and the parties continue to matter in Japanese elections-including under conditions of two-party competition. To illustrate these points, I trace the evolution of interest group politics from the era of LDP dominance through the rise of two-party competition and the LDP's recent return to power, using postmasters associations and agricultural cooperatives as case studies. KEYWORDS: agricultural cooperatives, bureaucracy, elections, exchange relationships, interest groups, political parties, postmasters associations
\end{abstract}

On July 21, 2013, Japan's Ruling Liberal Democratic Party (LDP) won a comfortable majority in the twenty-third upper house election. More than just a milestone in the LDP's return to power after spending more than three years (2009-2012) in the political wilderness, the victory promised to usher in an era of more proactive, reformist politics after years of legislative logjams caused by a 
"twisted Diet" (nejire kokkai) — the control of both chambers by opposing parties.

A closer look at the election returns, however, reveals that the road to reform is still littered with impediments. Of particular note is evidence of a small but significant upsurge in the power of interest groups representing noncompetitive sectors of the economy. Of the LDP's eighteen lawmakers who were elected as individual candidates in the national proportional representation (PR) district, the top, second-, fourth-, sixth-, seventh-, and eleventh-place finishers in terms of the number of votes received were the official representatives of the postmasters associations, agricultural cooperatives, medical groups, and other interest groups that at one time stood at the heart of the LDP's electoral machine (Asahi Shimbun, July 22, 2013). What is more, at least two of those groups-the postmasters and the farmers-mobilized more votes behind their chosen candidates than in 2010 (see the Appendix). Well known for resisting change in the past, these groups have become thorns in Prime Minister Abe Shinzō's side as he pursues his reformist agenda.

The 2013 electoral returns are puzzling. From the mid-1990s, many scholars cautiously predicted a steady decline in interest group power as new electoral rules incentivized politicians to court the floating vote (e.g., Koellner 2002; Rosenbluth and Thies 2010; Scheiner 2006; Thies 2002). To be sure, these predictions have been at least partially fulfilled; interest groups have indeed lost influence as the political system gradually approaches the Downsian ideal of "responsible party government," with the LDP and the Democratic Party of Japan (DPJ) competing more and more along programmatic policy lines for the support of the independent voter. But recent elections reveal that interest groups have significant electoral staying power. How can we explain this phenomenon?

Part of the answer is that politicians face lingering electoral incentives to court the organized vote. On their own, however, electoral theories do not fully explain why politicians turn primarily to economically noncompetitive groups for support, as opposed to business conglomerates and their representative organizations. The primary reason for this, I argue, is interest group organization. Many of Japan's large, economically noncompetitive interest groups have been positioned to carry out vote-gathering functions for political parties that have been ill equipped to perform such functions themselves. Interest groups assumed these tasks as a result of their large, multitiered organizations that connect grassroots society to the high- 
est levels of national power-organizations that for the LDP's top vote mobilizers developed out of their historically close ties to the bureaucracy. To illustrate these points, I examine the organizational evolution and electoral activities of two of Japan's most influential groups: the agricultural cooperatives and especially the postmasters associations, both of which in their heyday gathered more than 1 million votes behind their LDP "sponsored candidates" in upper house elections. ${ }^{1}$

While Japan scholars have long focused on the changing electoral factors that incentivize politicians to court the organized vote, few have acknowledged the importance of interest group structures in Japanese electoral politics and the organizational complementarities between interests and parties that subsequently ensue (see, e.g., Curtis 1971; George Mulgan 2000). No one, moreover, has systematically explored the historical roots and changing dynamics of those complementarities. In so doing, I draw attention to the interaction between electoral and organizational factors and in ways that more fully illuminate the marketplace of interest group politics. In addition to explaining why some groups matter more than others in Japanese electoral politics, attention to organization as well as electoral incentives leads to more nuanced insights into why the vote yields of key groups can fluctuate under constant electoral rules. It also enables us to identify the range of electoral functions assumed by key groups-functions that include not only mobilizing the vote but also self-monitoring their performance of that function and coordinating it across multiple constituencies. Finally, the approach helps explain the shifting dynamics and consequences of groupparty synergies under conditions of both one-party dominance and two-party competition.

This article also illuminates hitherto unexplored implications of the Japanese bureaucracy's linkages with interest groups. The idea of state influence over societal groups in advanced industrialized democracies is nothing new; scholars-many of them writing in the corporatist tradition-long ago explored the significance of this interrelationship in the comparative politics and Japan studies literatures (see, e.g., Berger 1981; Hamamoto and Tsujinaka 2010; Pempel and Tsunekawa 1979; Schmitter 1979). But while scholars have done a thorough job in assessing the ramifications of the interest group-bureaucracy partnership for patterns of interest representation and public policy, they have largely overlooked how that partnership can shape group behavior in elections. Again, it has done so in the 
Japanese case by generating complex organizational structures that empower interests to co-opt important vote-gathering functions from the parties.

Finally, while cross-national comparisons are beyond the scope of this study, the following pages resonate with renewed attention in political science to the significance of interest group organization for many of the challenges that currently confront democracies. In recent studies of growing income inequality and the inequality of political representation in the United States (e.g., Hacker and Pierson 2010; Schlozman, Verba, and Brady 2012), for example, Schattschneider's (1960) famous but oft-neglected observations about the centrality of interest organization for elections and policymaking are experiencing something of a renaissance. One of my purposes in this article is to direct attention to the synergies that can exist between particular organizational patterns of interest representation and political party structures-synergies that in the Japanese case operate as a powerful brake on neoliberal economic reform.

The discussion proceeds as follows. First, I explore the bureaucratic origins of interest group organization, illustrate how and why groups like the postmasters associations and co-ops were mobilized during the era of LDP dominance (1955-1993), and identify the electoral functions that these groups performed. In the next two sections, I analyze the various factors that contributed to the declining party demand for and organizational supply of interest group support since the early 1990s, culminating in Prime Minister Koizumi Jun'ichirō's 2005 strategic attack on the organized vote. Here, I argue that while Koizumi's gambit failed to permanently diminish what remained of the demand for and supply of the organized vote, by weakening group loyalties toward the LDP, it helped pave the way toward a period of intense interparty competition for the organized vote. In the concluding section on interest group politics in the wake of the LDP's 2012 return to power, I examine deepening tensions between the party's ongoing dependence on the organized vote and its quest for neoliberal reform, and highlight the potential for further change.

\section{The Bureaucracy-Interest Group Nexus and Group Power Under LDP Dominance}

By the early 1980s, the postmasters associations, agricultural cooperatives, and groups representing the professions and other economically noncompetitive interests had become important cogs in the vast 
electoral machine that helped fuel LDP dominance. In election after election, these groups delivered large blocks of votes behind individual candidates in return for preferential prices, market protectionism, and a host of other particularistic policy favors.

Most explanations of interest group power during this period focus on electoral rules that incentivized ruling-party candidates to court the organized vote. In the lower house, the pre-1994 single nontransferable vote, multimember district system (SNTV) encouraged LDP candidates in each district to divide the vote among themselves by cultivating the personal vote and the support of local interest groups (see Scheiner 2006, 76). Similarly, in the multimember national district of upper house elections that was in place until 1982, politicians running as individual candidates would simplify the votegathering process by appealing to one or a few large interest groups. Those lawmakers who openly championed the interests of their organized supporters in the corridors of power were known as "sponsored candidates" (rieki daihyo giin [interest representation Diet members]). Candidates in both chambers were further incentivized to rely on the organized vote by the country's short campaign period and draconian restrictions on the dissemination of electoral information (Curtis 1971; George Mulgan 2000, 380; Koellner 2002, 117; Thies 2002, 95-96).

While electoral explanations undoubtedly illuminate the forces that shaped LDP demand for the organized vote, they nevertheless paint an incomplete picture of the electoral marketplace by neglecting the nature of the supply of such support. One question electoral models cannot answer, for instance, is why targeted groups were economically noncompetitive interests, as opposed to wealthy industrial groups.

One obvious explanation for the preeminence of economically noncompetitive interests in terms of mobilizing the vote is that these groups had far more to gain from their electoral ties with the LDP than did well-off business groups (see, e.g., Ishida 1974). By allying with the ruling party in the context of Japan's heavily centralized system of public finance, needy groups significantly increased their chances of gaining access to the public trough (see Scheiner 2006). But these groups also had something to offer the LDP that business groups lacked: the organizational capacity to perform important electoral functions on a national scale. For many groups, this capacity was a product of their historically rooted linkages to the bureaucracy. 


\section{The Bureaucracy-Interest Group Nexus}

Many of Japan's largest interest groups got their start during the late nineteenth and early twentieth centuries, a time when the bureaucracy was extending its regulatory reach throughout the economy and society in its efforts to rationalize and accelerate the processes of rapid economic development. In what may be a classic case of corporatist patterns of interest group formation, the bureaucracy licensed many - but by no means all-organized interests by either approving preexisting groups or establishing new ones from above (Ishida 1968, 302; 1974; Steslicke 1973, 36-44). In both cases, licensing was entrenched in law and groups were subjected to varying degrees of regulatory controls-especially those that were contracted to carry out government functions.

And so it was with the agricultural cooperatives and the postmasters associations. Although farmers had long shown signs of spontaneous organization at the local level, the prewar prototypes of the cooperatives were ultimately established by bureaucratic statute and entrusted with the distribution of the national rice supply and other tasks relating to food security (Bullock 1997). Similarly, bureaucrats from the early 1870 s controlled the establishment-and, on subsequent occasions, reorganization-of associations of commissioned (or "special") postmasters (tokutei yübinkyokuchō) who played a leading role in the implementation of the mail, postal savings, and insurance services.

As they went about the business of executing state programs, these groups received a variety of resources from the bureaucracy. By the early postwar era, the postmasters enjoyed generous rents for their (privately owned) postal facilities and large monthly allowances (watarikirihi) for post office operations that they dispensed at their discretion. The farmers were guaranteed minimum incomes through government price support programs for rice and other commodities. And by the early postwar period, both the farmers and the postmasters were either direct or indirect beneficiaries of a wide gamut of financial and welfare services offered by institutions within their respective organizational networks - institutions that were themselves overseen and protected by bureaucrats. All the while, the two groups enjoyed de facto lifetime employment, a perquisite that their respective bureaucratic benefactors helped guarantee as they fought against mounting calls for the reform or even outright dismantling of the commissioned postal system and agricultural price supports. These and related resources gave postwar farmers and postmasters a 
major stake in the status quo that they routinely defended in both the electoral and policy spheres.

For our purposes, the most significant resource bestowed by the bureaucracy on affiliated interest groups was organization. To facilitate the implementation of government programs, bureaucrats oversaw the formation and subsequent expansion of intricate organizational networks that established clear hierarchies of authority within group memberships. By the early postwar period, Nokyo, the national association of agricultural cooperatives that was later renamed the Japan Agricultural Cooperatives (JA), had evolved into a massive, three-tiered structure that paralleled national, prefectural, and local units in the agricultural ministry (George Mulgan 2000, 67). Nokyo later developed a political arm, the National Federation of Agricultural Policy Campaign Organizations (Zenkoku nōseiren). By 2013, JA consisted of more than 9.5 million members-staff members as well as farmers. Similarly, private citizens contracted by the state from the 1870 s to carry out postal functions found themselves enmeshed in a vast organizational network that mirrored the communications bureaucracy. ${ }^{2}$ Bureaucrats imposed strict controls on both federations-particularly, it appears, in the postmasters' case, given their role as official representatives of the state at the local level. Subjected to a dizzying array of regulations that restricted virtually all forms of independent action (see Yamaguchi 1993), the postmasters became a veritable appendage of the Communications Ministry by the early 1940 s.

Bureaucratic involvement in the affairs of major interest groups continued well into the democratic era, but in a less intrusive fashion. Officials helped reconstitute many interest group associations during the occupation period (1945-1952), focusing on groups like the postmasters and farmers that continued to carry out government functions (for agriculture, see Pempel and Tsunekawa 1979, 159). In 1953, the postmasters established Zentoku, their main lobbying group, which was grafted over the federation of postmasters organizations that had been in place at war's end. Bureaucrats voiced their approval of the association - a controversial move given Zentoku's legal status as a "voluntary" organization (nin'i dantai) (Wada 1997, 121) - and then went on to establish Tokusuiren, an official organ for the administration of postal functions that duplicated the organizational networks and memberships of Zentoku. It was through these two organizations that Japan's approximately 19,000 (as of the late twentieth century) commissioned postmasters conducted their affairs and interacted 
with both the bureaucracy and, eventually, the LDP. Also significant was Taiju, a national association of retired postmasters and the spouses of active postmasters that formed during the 1980s and that mirrored the organizational structure of its sister associations. Since retired postmasters are not subject to the legal restrictions that limited the political activities of active postmasters, Taiju's roughly 100,000 members played a prominent role in elections.

Their close association with the bureaucracy and dense organizational networks positioned the postmasters associations and co-ops to develop a number of other strengths that later proved advantageous in the electoral sphere. They monopolized-or nearly monopolized, in the co-ops' case- the representation of their respective constituencies. For the postmasters, the posts ministry made membership in Tokusuiren - and, by default, in Zentoku - compulsory. And for the farmers, Nokyo membership was required in practice since the government had granted the co-ops a virtual monopoly over the distribution of special loans and government subsidies (M. Honma 2014, 88; Pempel and Tsunekawa 1979, 250). Their monopolization of representation in turn enhanced the authority of both groups in the policy process, to which they enjoyed privileged access, as well as the electoral sphere. (This is in marked contrast to the labor unions, whose more spontaneous development during the postwar era contributed to the establishment of competing federations that ultimately weakened labor's voice in the electoral sphere.)

The co-ops and the postmasters associations also served as conduits for both systematized interaction between local and national Japan and for bureaucratic contact with grassroots citizens, a level of society that would have otherwise remained outside of the national bureaucracy's effective reach. Nokyo was grafted over the dense social networks that had traditionally characterized rural hamlets (George Mulgan 2000, 213). And Zentoku and Tokusuiren penetrated the very heart of neighborhoods in rural and urban Japan alike through local units of ten post offices each. Given the presence of post offices within virtually every community in Japan-indeed, within a child's walking distance-one is hard pressed to find an interest group that is more geographically inclusive and in tune with local residents who could later be mobilized for electoral purposes.

Whereas the postmasters associations and, to a lesser extent, Nokyo were inclusive, hierarchically structured, and tightly knit federations, the same cannot be said for the country's leading business and industrial associations. This distinction can be explained in part 
by the nature of the relationship between corporate Japan and the bureaucracy. To be sure, pre-1945 business interests were no strangers to government interference on behalf of the state's developmental goals (see Schaede 2000, 245-246). But they were also private sector entities that enjoyed a degree of freedom to organize and conduct themselves as they saw fit. Representative federations of the business community were thus far less inclusive, more weakly represented at the local level (with the notable exception of the Japan Chamber of Commerce), and characterized by higher levels of internal diversity and subgroup autonomy than the postmasters associations and the co-ops (see Pempel and Tsunekawa 1979). As a result, business groups may have become important sources of funds for the conservative parties, but their organizational structure rendered them poor conveyors of the vote.

\section{Mobilizing the Vote: 1955-1993}

Following its formation in 1955, the LDP faced major electoral uncertainties thanks to its weak organizational networks and ongoing challenges from the Japan Socialist Party. The party's prefectural chapters played virtually no role in electoral competition among LDP candidates for lower house seats; nor did party headquarters do much to coordinate upper or lower house campaigns across constituencies (Shinoda 2013, 27). The LDP's grassroots presence, meanwhile, was largely limited to the weakly staffed constituency offices of individual Diet members. To compensate for these organizational handicaps, the party encouraged candidates to establish individual support groups, or kōenkai, to help them gather the "personal vote" (see Reed 2009; Shinoda 2013, 27-29). Many conservative politicians also looked to organized interests for support.

Tanaka Kakuei, Japan's prime minister between 1972 and 1974 and arguably the LDP's most skillful broker until his death in 1993, did more than any other conservative politician to hitch interest groups to the ruling party's electoral wagon. And he focused primarily on groups representing economically noncompetitive sectors of the economy that had a strong organizational presence at both the local and national levels. The clever Tanaka recognized in the construction industry, small business associations, and particularly the agricultural cooperatives and the postmasters associations their capacity to compensate for the LDP's weak organizational roots in local communities. In short order, a series of quid pro quo relationships between the party and these interest groups was established in 
which the latter delivered large blocks of votes to LDP candidatesmost notably members of the burgeoning Tanaka faction-in return for particularistic favors. Such relationships are customarily referred to as "clientelistic" in the Japanese politics literature, but this term is misleading. For in its presupposition of an inherently unequal power relationship that privileges the party-as-patron, the term clientelism exaggerates the power of the party and understates the contributions of interest groups to long-term LDP dominance. To avoid such misrepresentations, I refer to these interest group-party linkages very simply as "exchange relationships" (see also Norgren 2001).

While Japan scholars have long recognized the importance of interest groups in mobilizing the so-called hard vote (koteihyō) behind individual politicians (see Curtis 1971; George Mulgan 2000 ), little is known about the dynamics of such practices. I argue that the electoral importance of large interest groups like the co-ops and the postmasters associations lies in their organizational capacity to effectively perform three sets of interdependent functions: (1) mobilization functions, which include gathering the local vote and recruiting both LDP members (tōin atsume) and kōenkai members (kōenkai kaiin atsume); (2) self-monitoring, defined here as the intragroup monitoring of mobilization functions; and (3) the coordination of mobilization activities across constituencies.

George Mulgan's description of vote gathering by co-op leaders during the late 1950s reveals evidence of mobilizational and coordination functions:

The system was basically hierarchical with the directives (or requests) coming down through the pipeline of intermediary power brokers, including the leaders of local organizations such as the agricultural cooperatives, via the hamlet to the voter. At the bottom of the hierarchy was the head of the farm household who directed the votes of its members. $(2000,383)$

Co-op leaders and especially the postmasters also performed mobilizational functions outside of their associational and familial boundaries by nurturing their local social status as "opinion leaders." The postmasters worked hard both during and after working hours to cultivate their personal links to local residents-or chiensei (territorial bonds), as they called them-in part by volunteering for various forms of community service (Maclachlan 2011, 124-129). The trust that such activities generated in the postmasters proved highly advantageous for electioneering purposes. 
Both the postmasters associations and the co-ops coordinated these mobilizational functions across different electoral constituencies. As George Mulgan observes, the sheer size and diversity of co-op networks weakened Nokyo's efforts to coordinate local vote endorsement decisions and mobilizational efforts from the national level (2000), although it appears that such functions were regularly carried out at the prefectural level. Coordination functions proved much easier for the national leaders of the postmasters associations to perform, thanks in large part to their smaller and more cohesive memberships (see Maclachlan 2011).

Virtually no research has been conducted on the self-monitoring activities of large Japanese interest groups. As political scientists have shown, forcing compliance with the contractual obligations of vote gathering is critically important to the long-term survival of various forms of electoral exchange relationships (see Kitschelt and Wilkinson 2007). In clientelist political systems, monitoring usually targets individual voters to prevent them from reneging on their obligation to support a designated party or politician in return for some kind of payment; in Taiwan, this particular function is typically carried out by party organizations, candidates, or individual third-party brokers (Wang and Kurzman 2007). In postwar Japan, by contrast, it was the intermediaries-kōenkai, interest groups, and local and prefectural politicians - that were being monitored. As Scheiner (2006, $15,72-75$ ) observes, sometimes the LDP did the job itself. But it was also the case that interests like the co-ops and the postmasters were monitoring themselves, thanks to their organizational capacity to impose predictable compliance procedures on their members (see Medina and Stokes 2007, 75).

The postmasters associations proved particularly adept at inhouse monitoring. New postmasters, many of them the sons of postmasters and vetted by local LDP Diet members, would be inducted into the world of electoral politics within their first two years in the profession. Higher-ups assigned them quotas (noruma) not only for the number of votes gathered during electoral campaigns but also for the recruitment of kónkai and party members from among the residents of the neighborhoods they served. The postmasters were required to submit the signatures of their recruits to their superiors, who carefully tracked their performance (Curtis [1971, 189-193] observed similar practices among local dentists groups during the 1960s). Following an election, the postmasters' performance was publicized within local chapters of Zentoku, and those who fell short 
of their quotas were subject to censure (S. Honma 2003, 147). The postmasters' ability to deliver 1 million or more votes in election after election suggests that intragroup monitoring successfully curbed postmaster defections from their electoral responsibilities. To wit, many postmasters took those responsibilities seriously enough to dip into their government allowances (watarikirihi) or personal savings to pay the party membership dues or kōenkai fees of new recruits. As the decades unfolded, electioneering consumed so much of the postmasters' time that it was dubbed the post office's "fourth service" (daiyon jigyō), after the mail, postal savings, and postal insurance services (see Maclachlan 2011; Enō 2006; S. Honma 2003).

In some instances, bureaucrats participated in the performance of coordination and monitoring functions. Woodall observes in the case of the construction industry that linkages designed to promote cooperation-or "collusion," as some would have it-between Ministry of Construction bureaucrats and large construction firms during the bidding processes for government procurement projects could be mobilized to ensure the proper execution of electoral functions (Woodall $1996,39,77)$. In the postmasters' case, low-ranking bureaucrats who were closely linked to the postmasters through Tokusuiren, the postmasters' administrative organization, worked in secret consultation with LDP strategists and leading postmasters at the national level to help devise, distribute, and coordinate quotas to postmasters across different districts. It was then up to the postmasters' local and regional superiors within the postmasters associations to monitor their fulfillment of those quotas. ${ }^{3}$

As a result of their organizational capacity to co-opt certain electoral functions from the LDP, interest groups like the postmasters associations and Nokyo could exercise a degree of independent leverage over the conservative party. Such leverage was evidenced by glaring displays of disloyalty toward the LDP over the years-of the co-ops' playing the party's pre-1955 conservative predecessors against each other during negotiations over the producer rice price (George Mulgan 2005, 285; Davis 2003, 124), of the farmers' staying home on election day to voice their disapproval of agricultural liberalization policies during the 1980s and 1990s, and of the postmasters' threatening to renege on their electoral duties whenever talk of radical postal reform heated up. Interest groups may not have fully achieved their policy objectives in these instances, but given the LDP's long-standing conservatism on agricultural liberalization and 
postal privatization, they were undoubtedly making an impression on the party.

\section{Interest Groups in Decline: Post-1993}

While the early 1980 s marked the high point in the electoral power of interest groups, the period sandwiched between the end of LDP dominance in 1993 and the 2005 lower house election witnessed its partial decline.

Electoral reform certainly contributed to this decline by weakening party demand for the organized vote. The 1994 changes to the lower house electoral system, which replaced the SNTV system with a mixture of single-member districts (SMDs) and PR districts, strengthened incentives for interparty competition along programmatic lines for the support of Japan's expanding cohort of independent voters. Meanwhile, the 1982 transformation of the upper house's national multimember district into a closed-list, PR district eliminated individual candidacies and thus weakened incentives for candidates to reach out to organized interests. This blow to interest group power was subsequently softened first by the expansion of opportunities for groups to influence the placement of candidates on the party list (see Koellner 2002, 122) and then, in 2000, by the shift to an open-list system that permitted voters to vote for either a candidate or a party.

On the supply side of the equation, the quality of interest group organization was deteriorating. A number of factors contributed to this trend, not least of which were the effects of such long-term demographic developments as urbanization and the decline of community. For groups like the postmasters associations that gathered the vote outside of, as well as from within, their memberships, these developments made it increasingly difficult for local postmasters and other "men of influence" to mobilize voters. George Mulgan (2000, 2005) observed similar developments among political opinion leaders within the co-ops, which suffered an additional blow from the steadily declining population of farming households over the years.

Many groups were also experiencing conflicts of interest among their rank-and-file memberships. The co-ops struggled with widening fissures between full- and part-time farmers (Koellner 2002, 118-119; George Mulgan 2005, 264). The postmasters remained more unified than the farmers, but even they faced internal dissention as younger postmasters balked at their onerous electoral quotas (see 
Enō 2006; S. Honma 2003). Meanwhile, both the postmasters and the farmers were rapidly aging and preoccupied with their quests for suitable successors.

The organizational decline of interest groups was exacerbated by economic and bureaucratic reforms. Reductions during the late 1990s and 2000s in the size of the Fiscal Investment and Loan Program hit rural interests particularly hard-especially part-time farmers who depended on public works projects for supplementary employment. ${ }^{4}$ The partial deregulation of agricultural markets weakened JA's capacity to dominate the provision of agricultural inputs and other services to farmers (George Mulgan 2005, 264). Prime Minister Koizumi's threats to drastically reduce agricultural price supports intensified conflicts between full-time and part-time farmers, while his 2005 postal privatization legislation stripped the postmasters of some of their financial and welfare perquisites, and of the public servant status that for many years had been a focal point of their collective identity. The postmasters also lost many of their valuable linkages to the bureaucracy in 2007 as much of the business of administering the postal services was transferred to the corporations of the Japan Post Group. All the while, efforts to reduce the size and influence of the bureaucracy in the Japanese political economy via the reform of ministerial advisory councils (shingikai) (see Hamamoto and Tsujinaka 2010), the establishment of the supraministerial Council on Economic and Fiscal Policy (CEFP), and the reform or elimination of public corporations reduced group access to their bureaucratic contacts and to various financial and informational resources.

All told, these reforms weakened the capacity of interest groups to dominate the representation of their respective populations; speak with a unified voice in the electoral sphere; and bring a wide gamut of resources to bear on their vote mobilization, coordination, and monitoring functions. Gone were the days when large groups could mobilize 1 million or more votes at election time.

Against this backdrop, Prime Minister Koizumi moved to further weaken the organized vote. By calling a snap lower house election for September 11, 2005, and refusing the party's endorsement of lawmakers who had opposed his postal privatization bills, Koizumi forced his party to sever its long-standing exchange relationship with the postmasters. Almost overnight, the postmasters associations lost their capacity to coordinate their vote-gathering functions from the national level. Since the LDP no longer served the postmasters' inter- 
ests, Zentoku and Taiju advised their local chapters to make their own decisions as to which candidates to support. In some districts, the chapters backed the "postal rebels," who ran as independents or members of new splinter parties. In districts where no rebels were running, some chapters backed DPJ candidates, while others stuck with the LDP in the hopes that Koizumi was just a passing phenomenon (see Maclachlan 2006, 2011).

Koizumi's attack on his party's exchange relationship with the postmasters affected other large interest groups as well. Fearful that the success of postal privatization might soon lead to unwelcome reforms in their own policy spheres, the co-ops, construction firms, and medical associations looked beyond the LDP to the opposition parties (Maclachlan 2006). Some groups took these steps weeks before the 2005 election, when their erstwhile LDP patrons in the lower house opted to support postal privatization (Asahi Shimbun, August 21, 2005). Many followed the postmasters' lead by decentralizing candidate endorsement decisions to local chapters as they grappled with growing dissention among their memberships. It appeared, in short, that Koizumi had dealt the already weakened organized vote a coup de grâce.

\section{Contemporary Interest Group Power Under Two-Party Competition}

Appearances, of course, can be deceiving. Koizumi may have marginalized what remained of interest group power during the 2005 election, but the effects of his efforts proved to be short-lived. As subsequent events revealed, Koizumi failed to eliminate what remained of LDP demand for the organized vote; nor did he permanently alter the organizational capacity of key groups to deliver it. What Koizumi did do was destroy interest group loyalties toward the LDP, and in so doing help usher in a new era in which the DPJ and the LDP actively competed for the organized vote. The manner in which these trends unfolded reflects the continuing organizational complementarities between interest groups and parties in the electoral sphere under conditions of two-party competition.

\section{Why the Organized Vote Still Mattered-}

Even Under Koizumi

Koizumi may have relished his role as the enemy of special interests, but he was actually quite solicitous of them during the early stages of 
his prime ministership. Between 2001 and 2004, he tried to have it both ways by simultaneously wooing the floating vote and the organized vote-what scholars have called killing two birds with one stone (Mori 2008) or "hybridized election campaigning" (Koellner 2009, 139). The policy inconsistencies inherent within this strategy proved untenable by the 2004 upper house election, when the ruling party lost ground to the DPJ among both floating voters, who were frustrated with the slow pace of structural reform, and organized interests opposed to change. It was only then that Koizumi opted to abandon special interests (Mori 2010, 180-181).

As soon as Koizumi left office, his successor took steps to return to the status quo ante. In autumn 2006, Prime Minister Abe Shinzō readmitted eleven postal rebels into the party, appointing two of them a year later to senior vice-ministerial positions (Japan Times, August 29, 2007); yet another rebel, Noda Seiko, went on to become a cabinet minister in 2008. Abe then stood back as the postmasters forced postal authorities to preserve at least some of their authority in the successor organization to Tokusuiren and to scale back plans for an overhaul of the old commissioned post office system, which was so essential to the postmasters' penetration of local neighborhoods. Abe's efforts to recapture the hearts - and votes - of the postmasters ultimately failed, thanks in part to the LDP's 2005 electoral mandate to uphold Koizumi's postal privatization legislation; in the 2007 upper house election, the postmasters associations threw their support behind a number of People's New Party (PNP) and DPJ candidates - rather than a single LDP-backed "sponsored candidate"-in both the PR and prefectural districts. (Abe had better luck in 2007 wooing the farmers, who mobilized nearly four times as many votes behind their preferred LDP candidate than in 2004.) By contributing to the preservation of at least some of their organizational resources, however, Abe helped the postmasters recoup some of their post-2005 electoral power.

The LDP's post-Koizumi efforts to recover its old exchange relationships reflect lingering electoral incentives for the parties to court the organized vote. Some of those incentives, such as the continuation of short campaign periods and the relative empowerment of the farm vote as a result of the continuing malapportionment of rural districts, survived the electoral reforms of the 1980s and 1990s. Others are new - or unanticipated. Most fundamentally, the PR tier of both houses encourages candidates to reach out to the organized vote as they seek to maximize their share of the popular vote. Interest groups 
also matter to a degree within lower house single-member districts. The winner-take-all format of SMDs may encourage the parties to compete more along programmatic lines, but no candidate has the electoral machinery at his disposal to win solely on the basis of appeals to the fickle floating voter (Krauss and Pekkanen 2011; Mori $2010,180)$. Organized interests help fill that gap. Also significant has been the so-called dual candidacy system, whereby candidates for the lower house - particularly incumbents whose seats are in jeopardyrun simultaneously in both the SMD and PR tiers. In the PR tier, candidates are usually lumped into a single slot on a closed party list and then ranked after the election according to their performance in the SMD. Interest groups come into play by helping these candidates snare as many votes as possible in the SMD-even when victory there appears hopeless (Bawn and Thies 2003, 22; Koellner 2009, 131; Scheiner 2006, 80).

On the supply side of the equation, economically noncompetitive interest groups looked to exchange relationships with politicians as a hedge against economic and bureaucratic reforms that were reducing group access to essential resources. Moreover, these groups still had something to offer politicians who were struggling with mounting electoral uncertainty under conditions of increasing interparty competition: the organizational capacity to perform electoral functions.

Interest Groups

Under Interparty Competition: 2007-2012

The breakdown in interest group loyalties toward the LDP can be seen in group efforts to diversify their political party contacts. The second Japan Interest Group Survey (JIGS2) of nearly 16,000 groups highlights the early stages of this trend. ${ }^{5}$ The survey revealed that while the ruling LDP was still the preferred party for the overwhelming majority of nonlabor groups between 2005 and early 2007, many groups with close ties to the conservative party were beginning to reach out to the DPJ as well, particularly in regions where the DPJ's seat ratio had been increasing (Hamamoto 2010, 18).

The farmers, who had a long history of punishing the ruling LDP at the polls when it suited them, were among the first to establish or deepen ties with the DPJ. Criticisms of the LDP had reached new heights during the early 2000 s, particularly among inefficient, parttime farmers who outnumbered their full-time counterparts by nearly three to one and who stood to lose the most from the LDP's pledge to 
reduce agricultural price supports and public works spending in the countryside. Although the farmers had few formal contacts with the DPJ in 2005, they were sufficiently disappointed in Koizumi's LDP to transfer some of their support to the opposition party in the September lower house election (Reed, Scheiner, and Thies 2012, 365).

As the 2000s wore on, the farm vote grew unpredictable. A survey of the co-ops and other farming groups in the Tohoku region conducted shortly after the 2010 upper house election showed that while 58 percent of individual farmers voted LDP and 36.9 percent DPJ in the PR district in 2007, the numbers for the PR district during the 2009 lower house election were more evenly divided, with 46 percent voting LDP and 41.3 percent DPJ (Kawamura 2011, 41). In a nod to the increasing disaggregation of the farm vote and the DPJ's electoral victory, JA announced after the 2009 lower house election that it would adopt a more bipartisan stance in the future. And so, in the subsequent 2010 upper house ballot, JA refused its official endorsement of the LDP's Monden Eiji, despite Monden's record as the leader of JA's youth organization, and advised prefectural chapters to decide for themselves whether to back the LDP, the DPJ, or both parties, or to allow the members a "free vote" (jishu tōhyō) (Kawamura 2012, 27). The farm vote proved to be so fractured by this time that Monden failed to win a seat, receiving just 80,381 votes, one of the lowest yields among those who ran as individual candidates on the LDP ticket. What is more, it appeared that many farmers were taking full advantage of the "free vote": according to the Tohoku survey noted above, while nearly half of Tohoku farmers voted LDP in the PR district and only a quarter for the DPJ, fully one-fifth-mostly low-income, part-time farmers - cast their ballots for smaller conservative parties like Tachiagare Nihon (Sunrise Party of Japan) and Minna no Tō (Your Party) (Kawamura 2011, 44-46).

Disillusion with the LDP's agricultural policies was not the only driver behind this breakdown in partisan loyalties; farmers were also influenced by the DPJ's growing power and promises that it would do more for the farmers than the LDP ever could. When Koizumi pushed to liberalize agriculture and cut public works spending in the countryside, the DPJ countered in 2004 by promising to increase national self-sufficiency in food production, a long-term co-op goal (George Mulgan 2005, 297). And in reaction to the LDP's policy to replace price supports with income subsidies for full-time commercial farmers, Ozawa Ichirō, DPJ general secretary and a political broker in the best tradition of Tanaka Kakuei, orchestrated a 2009 DPJ 
announcement that it would subsidize all commercial farmersincluding those who worked only part-time on small-scale, inefficient plots. The policy, which was introduced in FY 2011, less than two years after the DPJ seized power, soon comprised one-quarter of the government's budgetary expenditures on agriculture (Daily Yomiuri, December 11, 2012).

Prime Minister Kan Naoto (2010-2011) and his successor, Noda Yoshihiko (2011-2012), interrupted this game of interparty oneupmanship over the farm vote by pushing for Japan's participation in negotiations over the Trans-Pacific Partnership (TPP), a multilateral free trade pact that was committed, among other things, to tariff reductions in all sectors, including agriculture. But an onslaught of opposition from among DPJ rank-and-file Diet members ultimately forced Noda to shelve the plan in the lead-up to the 2012 lower house election (see George Mulgan 2014). Noda then resorted to another round of policy one-upmanship, promising the farmers that he would entrench his government's new income subsidies program for agricultural households in legislation should the DPJ win the election (Daily Yomiuri, December 11, 2012).

The farmers refused to budge. Although JA's political arm once again decentralized campaign endorsement decisions to its chapters, the majority chose to back LDP candidates in 2012. As George Mulgan observes, the move reflected co-op disillusionment with the DPJ's stance on the TPP and concerns about the dampening effects of both the TPP's and the DPJ's income supports on agricultural prices and hence JA's own profits. But agriculture was also swayed by the LDP's promises of a better deal. In an abrupt reversal of its 2009 position, the conservative party pledged to expand the agricultural budget to include, among other things, more funds for rural public works projects. It also promised to pursue the TPP only if exemptions from tariff reductions could be secured for agriculture. The ploy worked; the victorious LDP clinched 100 of 120 rural and semirural seats in 2012, a dramatic increase over the 46 seats it had secured in 2009 (see George Mulgan 2013).

The diversification of party ties also occurred within associations of physicians, dentists, local land improvement groups, the construction industry (Kawamura 2012, 25), and, of course, the postmasters. In 2004, the postmasters were experiencing internal divisions comparable to those that plagued the farmers, thanks in part to both fallout from a highly publicized 2001 electoral scandal that implicated many postmasters in the Kinki district and disagreement over how best to 
deal with Koizumi's mounting call for postal privatization. As a result of these divisions, the postmasters gathered only 282,919 votes behind their LDP-sponsored candidate in the 2004 upper house ballot, a significant drop from the 478,985 votes gathered in 2001 . When Koizumi cast the postmasters adrift during the 2005 election campaign, the postmasters pledged their allegiance to the PNP, the party of former LDP postal "rebels" that now carried the mantle of anti-postal privatization, or to DPJ candidates opposed to Koizumi's privatization blueprint.

By 2007, the postmasters distinguished themselves from many other interest groups by closing ranks behind the opposition partiesa feat made possible by their wholesale expulsion from the LDP camp and DPJ general secretary Ozawa Ichirō's willingness to tell them exactly what they wanted to hear. Willfully oblivious to the fact that many in his party had once advocated postal privatization, Ozawa forged a strategic partnership with the PNP after 2007 and personally informed Zentoku and Taiju leaders of the parties' commitment to unravel postal privatization in return for the postmasters' electoral support (Yomiuri Shimbun, December 16, 2008). As if on cue, the postmasters' associations rallied behind the DPJ and the PNP in the 2009 and 2010 elections, performing the same vote-gathering, coordination, and self-monitoring functions that it had once carried out for the LDP. In 2010, the postmasters rallied 406,587 voters behind their PNP candidate, former LDP-member Hasegawa Kensei, who ran with the DPJ's backing - a major improvement over their 2004 yield. (Hasegawa did not win a seat, however, since the PNP failed to attain the minimum share of the popular vote in the PR tier.)

Once in power, the DPJ-coalition government made good on its promises to the postmasters. After a series of false starts, the DPJ helped pass legislation in April 2012 to restore a substantial measure of government control over the postal services and to guarantee the longevity of the country's (inefficient) network of post offices and its many tens of thousands of employees. The reforms were strongly opposed by economists, private sector financial institutions, and even US insurance companies who viewed the government's recouped presence in the postal network as an impediment to financial liberalization and freer trade in services (Asahi Shimbun, April 12, 2012). Significantly, the LDP, now released from its obligation to uphold postal privatization following its defeat in 2009 , joined forces with the DPJ and the Kōmeitō, a small centrist party, to back the reforms. The political parties were in a race for the postmasters' support. 
No sooner was the ink dry on the new postal reform law than DPJ prime minister Noda Yoshihiko made his first appearance at Zentoku's annual national convention. When the LDP was in power, the postmasters would invite their sponsored Diet members and members of the postal zoku to attend these meetings; politicians from the opposition parties wisely stayed away. But at the 2012 meeting in Hokkaido, the DPJ was in charge. Sporting a necktie the same shade of red as Japan's signature mailboxes and waving a red handkerchief that had become a symbol of the antiprivatization movement, Noda reminded the gathering of 7,400 postmasters that he had been Zentoku's most vocal supporter during the party's recent presidential election. He went on to boast that his government's reform legislation had delivered Japan from the "worst evils" (saidai no heigai) of the Koizumi era. Seated prominently alongside the prime minister were several high-level LDP politicians (Mainichi Shimbun, May 27, 2012). The bipartisan showing was repeated at the 2013 meeting, which was attended by nearly 8,000 postmasters (Zentoku Online, May 2013).

Interparty competition for the organized vote was fueled by organizational complementarities between interest groups and the political parties-between groups that still had the capacity to mobilize significant numbers of votes and parties that were grappling with serious internal divisions. Although much has changed over the past generation, the LDP is still prone to factionalism. The party is also divided between second- and third-generation politicians whose local support bases (jiban) were built on the backs of well-organized interest groups, and younger politicians who are more adept at appealing to floating voters. The DPJ, for its own part, is still a hodgepodge of cliques and factions-some very informal and fluid, others more institutionalized (Koellner 2004) - representing unions, a number of former parties, and diverse ideological perspectives (Uekami and Tsutsumi 2011, 5-12). As Koellner (2004) observes, neither party has managed to devise an ideological or policy-oriented identity that transcends these subgroups. Nor have they managed to develop a more viable organizational presence at the local level, although the LDP has made some advances in that regard at the prefectural level. Large interest groups - or portions thereof - with networks penetrating the very grassroots of society help compensate for these party weaknesses come election time by promising sympathetic politicians an independent base of support. The vote yields of those groups, moreover, has tended to vary according to their degree of internal 
unity: the postmasters associations, which recovered much of their membership cohesion following the 2005 election, were positioned to deliver fairly consistent numbers of votes behind non-LDP politicians from election to election, whereas the yields of the more internally divided co-ops showed far more fluctuation over time in terms of both size and partisan preference.

The organizational complementarities between contemporary interest groups and the internally divided parties help explain party flip-flopping on the policy front. In the postal sphere, as we have seen, the LDP over the past decade has swung from being the party of the postmasters to proponents of neoliberal postal reform and then back again. The DPJ has experienced comparable swings. Similarly in the agricultural sphere, the two parties have vied with one another to be the foremost champion of either liberalization or protectionism. In both policy areas, moreover, each party has been known to trumpet conflicting policy positions as it juggles the demands of reformers versus antireformers and their respective interest group backers.

These observations suggest an alternative explanation for policy convergence between the LDP and the DPJ. In their recent contributions to this journal, Lipscy and Scheiner (2012) and Scheiner (2012) explain convergence as a function of the structure and operating rules of the lower house electoral system-most notably the "first-pastthe-post" principle in the country's 300 single-member districts-that incentivize the two main parties to converge their policy positions around the preferences of the median voter in each district. Viewed in this light, policy concessions to farmers reflect the wishes of wellinformed median voters who are concerned about rising socioeconomic inequality and other negative side effects of structural reform. While median voters may indeed be sympathetic to the plight of rural communities, this study strongly suggests that shifting policies toward farmers are as much, if not more, the product of the parties' continuing dependence on the co-ops' organizational capacity to deliver blocs of votes during elections-blocs of votes that in the first-past-the-post system of SMD districts may be just large enough to spell defeat for the inattentive candidate.

\section{Interest Group Politics Today}

Since late 2012, the LDP has partially recouped its supremacy among economically noncompetitive interest groups. This has not, however, signaled a return to the patterns of interest group politics that charac- 
terized the era of LDP dominance. Key groups are organizationally weaker than they were a generation ago and far more fickle in their partisan preferences. The parties, for their own part, still face conflicting electoral incentives to court both independent voters and the organized vote, and their overtures to interest groups continue to carry the mark of policy one-upmanship. Put simply, Japanese interest group politics are far more fluid and unpredictable than they once were. And more change may be on the horizon as the new LDP government takes steps to marginalize groups that oppose its reformist agenda - steps that evoke Koizumi's actions in 2005.

The status of the postmasters under Abe Shinzō's LDP government can be read as a test case of the extent to which the organized vote can still matter. The postmasters associations began to rekindle their old ties to the LDP after the party backed the DPJ's April 2012 postal reform legislation. Once the conservative party reestablished its bona fides on postal affairs, some postmasters concluded that it was time to "return the favor" (on o kaesu) (Asahi Shimbun, December 12 and 14, 2012). Others, however, remained mindful of the LDP's past betrayals and committed to the DPJ, which had led the charge against postal privatization after the 2005 general election (Asahi Shimbun, November 28, 2012). Given these partisan divisions among rank-and-file members, association leaders had no choice but to once again adopt a multipartisan or "omnidirectional" (zenhōi) stance, thus decentralizing the coordination of candidate endorsement decisions to prefectural chapters in the lead-up to the December lower house election. Although no aggregate data on these endorsements or the postmasters' final vote yield are available, anecdotal evidence gleaned from newspaper accounts indicates that association chapters followed their superiors' instructions to make their decisions on the basis of a candidate's "understanding of postal affairs," as opposed to their party affiliation (Asahi Shimbun, November 28, and December 3, 12, and 14, 2012).

In a noteworthy show of their vote-gathering skills, the postmasters closed ranks behind the LDP following its return to power. In February 2013, former Zentoku chief Tsuge Yoshifume announced that he would seek election to the upper house in July under the LDP banner (Mainichi Shimbun, February 15, 2013); Hasegawa Kensei, the postmasters' sponsored Diet member who had lost his seat in 2010, assumed the chairmanship of Tsuge's köenkai. In March 2013, the association leaders and the LDP, led by General Secretary Ishiba Shigeru, set aside their eight-year "grudge" (wadakamari) and agreed 
to forge a new electoral partnership (Tsūshin Bunka, March 11, 2013). Although the postmasters were no doubt aware of the merits of bandwagoning, we should not lose sight of the fact that the LDP was now pledging to do more than the DPJ at this time to support the Japan Post Group's pursuit of controversial new insurance and housing loans ventures (Daily Yomiuri, December 20, 2012). The LDP was duly rewarded; the postmasters delivered more votes $(429,002)$ to the party in the national PR tier of the July 2013 upper house election than any other interest group.

While the Abe government appears to have accepted the postmasters associations as a fixture on the current political landscape, it is showing far less tolerance toward JA as it pursues controversial agricultural reforms and trade liberalization. After angering JA in March 2013 with its decision to join TPP negotiations, the government is now taking steps to promote farmland consolidation and the corporatization of agriculture, both of which should decrease the number of inefficient part-time farmers who depend the most on JA's services; abolish the long-standing rice acreage reduction program (gentan), which JA administers; and inject more competition into agricultural markets. If successful, these and related policies will further weaken JA's organizational clout and resulting capacity to perform vote mobilization, coordinating, and monitoring functions.

At the same time, the government is seeking to outbid the DPJ in its provision of particularistic favors to the farmers. Some of those measures, like a pledge to double farm household incomes in ten years, look like fairly straightforward efforts to economically empower individual farmers. Others, including promises to increase Japan's rate of food self-sufficiency from 39 percent to 50 percent by 2020 , and to exempt rice and four other politically sensitive (or "sacred") commodities from detariffication under the TPP, are decidedly at odds with the government's professed commitment to agricultural reform and free trade. Still others, such as the decision to continue providing income subsidies to part-time as well as full-time farmers, suggest that the government is not yet prepared to completely alienate part-time farmers for the sake of reform. It appears, in short, that the Abe government wants to delink individual farmers from what remains of JA's controlling embrace and pull them into the LDP's electoral orbit. To date, the government has pursued this delicate balancing act with relative electoral impunity; in 2013, Yamada Toshio, a former JA official, received 338,485 votes in the PR tier of 
the July upper house election - a far sight less than the 449,182 votes he received in 2007, but second only to the postmasters' yield.

In many ways, Abe's not-so-subtle attack on JA resembles Koizumi's 2005 assault on the postmasters associations. But Abe has some advantages over his predecessor. First, his opponents are split on the question of free trade. Whereas Koizumi confronted an almost uniformly hostile population of postmasters during his postal privatization crusade, Abe enjoys some support for agricultural free trade among full-time farmers, many of whom have already reduced their dependence on the co-ops. Furthermore, Abe faces fewer electoral constraints than Koizumi did; public support for the DPJ is at a low point, the LDP occupies a comfortable majority in both chambers of the Diet, and there is no election on the horizon. In short, Abe appears better positioned than Koizumi ever was to permanently reduce the electorally significant organizational complementarities between a major interest group and antireformist elements of his party.

In sum, both the recent rapprochement between the LDP and the postmasters associations and the lengths to which the Abe government is now going to weaken JA's influence over agricultural politics attest to the lingering importance of the organized vote in contemporary Japan. Economically noncompetitive interest groups still matter in Japanese elections, and for reasons that reflect not only continuing party demand for interest group votes but also groups' organizational capacity to deliver them. Over the long term, we should expect these groups to face ongoing challenges in the electoral arena, thanks to their gradually deteriorating organizational cohesiveness in response to demographic trends and the effects of political-economic reforms, and to the determination of reformist politicians to reduce their political powers. For the time being, however, economically noncompetitive interest groups will continue to play a significant electoral role and to lead the political charge against neoliberal economic reform.

\footnotetext{
Patricia L. Maclachlan is associate professor of government and Asian studies at the University of Texas at Austin. She is author of Consumer Politics in Postwar Japan: The Institutional Boundaries of Citizen Activism and The People's Post Office: The History and Politics of the Japanese Postal System, 1871-2010 and coeditor of and contributing author to The Ambivalent Consumer: Questioning Consumption in East Asia and the West.
} 


\section{Appendix: \\ Upper House (PR Tier) Vote Yields of Postmasters and Farmers, 2001-2013}

Table 1 The Postmasters

\begin{tabular}{lccc}
\hline & Party & $\begin{array}{c}\text { Number of } \\
\text { Votes Received }\end{array}$ & $\begin{array}{c}\text { Individual Candidate } \\
\text { Ranking }\end{array}$ \\
\hline 2001 & LDP & 478,985 & $2 / 20$ \\
2004 & LDP & 282,919 & $3 / 14$ \\
2010 & PNP & 406,587 & Lost $(1 / 7)$ \\
2013 & LDP & 429,002 & $1 / 18$ \\
\hline
\end{tabular}

Table 2 The Farmers

\begin{tabular}{lccc}
\hline & Party & $\begin{array}{c}\text { Number of } \\
\text { Votes Received }\end{array}$ & $\begin{array}{c}\text { Individual Candidate } \\
\text { Ranking }\end{array}$ \\
\hline 2001 & LDP & 166,070 & $13 / 20$ \\
2004 & LDP & 118,540 & Lost \\
2007 & LDP & 449,182 & $2 / 14$ \\
2010 & LDP & 80,381 & Lost \\
2013 & LDP & 338,485 & $2 / 18$ \\
\hline
\end{tabular}

Source: Za Senkyo, various years. http://go2senkyo.com.

\section{Notes}

I wish to thank the following individuals for their very helpful comments on earlier drafts of this article: Stephan Haggard, Aurelia George Mulgan, Nemoto Kuniaki, Steven R. Reed, Kay Shimizu, Tanaka Aiji, Tsujinaka Yutaka, and two anonymous reviewers.

1. The observations of this study likely apply to other Japanese interest groups as well. While the postmasters associations and co-ops are by far the most representative examples of how bureaucratic linkages can position interests to effectively perform electoral functions, I expect similar observations to hold - to varying degrees - for at least the medical associations and the construction industry. Of course, not all electorally active societal interests have close ties to the bureaucracy, as the postwar labor union federations and the religious organization Sōka Gakkai illustrate (for the latter, see Klein and Reed forthcoming). This study suggests, however, that groups with bureaucratic linkages are politically advantaged by the nature of their resulting organizational networks, not to mention their privileged access to government financial and informational resources. 
2. Author interview with Zentoku official, Tokyo, March 27, 2003.

3. Author interview with Mainichi Shimbun reporter, Tokyo, January 23, 2003.

4. Formally established during the mid-1950s and known as the country's "second budget," the Fiscal Investment and Loan Program (FILP) is a massive public fund that the government invested in industrial expansion, public works projects, and other ventures. See Park (2011).

5. The second Japan Interest Group Survey, conducted between 2006 and early 2007, was led by Tsukuba University's Tsujinaka Yutaka.

\section{References}

Bawn, Kathleen, and Michael F. Thies. 2003. "A Comparative Theory of Electoral Incentives: Representing the Unorganized Under PR, Plurality and Mixed-Member Electoral Systems." Journal of Theoretical Politics $15,5: 5-32$.

Berger, Suzanne, ed. 1981. Organizing Interests in Western Europe: Pluralism, Corporatism, and the Transformation of Politics. Cambridge: Cambridge University Press.

Bullock, Robert. 1997. "Nokyo: A Short Cultural History." JPRI Working Paper, no. 41 (December). http://www.jpri.org/publications/working papers/wp41.html.

Curtis, Gerald. 1971. Election Campaigning Japanese Style. New York: Columbia University Press.

Davis, Christina L. 2003. Food Fights over Free Trade: How International Institutions Promote Agricultural Trade Liberalization. Princeton, NJ: Princeton University Press.

Enō Masaki. 2006. Jitsuroku: Tokutei yūbinkyokuchōsan [An authentic account: Mr. commissioned postmaster]. Tokyo: Shinpūsha.

George Mulgan, Aurelia. 2000. The Politics of Agriculture in Japan. London: Routledge.

- 2005. "Where Tradition Meets Change: Japan's Agricultural Politics in Transition." Journal of Japanese Studies 31, 2: 261-298.

- 2013. "Farmers, Agricultural Policies, and the Election." In Japan Decides 2012: The Japanese General Election, ed. Robert Pekkanen, Steven R. Reed, and Ethan Scheiner, 213-224. New York: Palgrave Macmillan.

- 2014. "Bringing the Party Back In: How the DPJ Diminished Prospects for Japanese Agricultural Trade Liberalization Under the TPP.” Japanese Journal of Political Science 15, 1 (March): 1-22.

Hacker, Jacob S., and Paul Pierson. 2010. Winner-Take-All Politics: How Washington Made the Rich Richer-and Turned Its Back on the Middle Class. New York: Simon and Schuster.

Hamamoto Shinsuke. 2010. "Changes Among Interest Groups Toward the Two-Party System." Social Science Japan Newsletter 42 (March): 16-20. http://newslet.iss-u.tokyo.ac.jp/ssj42/ssj42.pdf. 
Hamamoto Shinsuke and Tsujinaka Yutaka. 2010. "Gyōsei nettowaaku ni okeru dantai" [Groups in bureaucratic networks]. In Gendai shakai shüdan no seiji kinō: rieki dantai to shimin shakai [The political functions of contemporary social organizations: Interest groups and civil society], ed. Tsujinaka Yutaka and Mori Hiroki, 156-179. Tokyo: Bokutakusha.

Honma Masayoshi. 2014. Nōgyō mondai: TPPgo, nōsei wa kō kawaru [Agricultural issues: how agricultural policy will change after TPP]. Tokyo: Chikuma shinsho.

Honma Shūichi. 2003. Tokutei yūbinkyokuchō ni natta boku no rakudai nikki [My diary as a failed commissioned postmaster]. Tokyo: Shinpūsha.

Ishida, Takeshi. 1968. "The Development of Interest Groups and the Pattern of Political Modernization in Japan." In Political Development in Modern Japan, ed. Robert E. Ward, 293-336. Princeton, NJ: Princeton University Press.

_. 1974. "Interest Groups Under a Semi-Permanent Party: The Case of Japan." Annals of the American Academy of Political and Social Science 413 (May): 1-10.

Kawamura Kazunori. 2011. "Rieki dantaiuchi no dōtai to seiken kōtai" [Interest group dynamics and regime change]. Nenpō seijigaku, 33-51.

- 2012. "Seiken kōtai jidai no rieki dantai to sono henyō: 2010nen sangiinsen de no nōgyōhyō no yukuei kara" [Interest groups and their structure in the era of regime change: The outcome of the agricultural vote in the 2010 upper house election]. Komei (March): 24-30.

Kitschelt, Herbert, and Steven I. Wilkinson. 2007. "Citizen-Politician Linkages: An Introduction." In Patrons, Clients, and Policies: Patterns of Democratic Accountability and Political Competition, ed. Herbert Kitschelt and Steven I. Wilkinson, 1-49. Cambridge: Cambridge University Press.

Klein, Axel, and Steven R. Reed. forthcoming. "Religious Groups in Japanese Electoral Politics." In Kōmeitō: Politics and Religion in Japan, ed. George Ehrhardt, Axel Klein, Levi McLaughlin, and Steven R. Reed. Berkeley: Institute of East Asian Studies, University of California.

Koellner, Patrick. 2002. "Upper House Elections in Japan and the Power of the Organized Vote." Japanese Journal of Political Science 3, 1: $113-137$.

- 2004. "Factionalism in Japanese Parties Revisited or How Do Factions in the LDP and the DPJ Differ?" Japan Forum 16, 1: 87-109.

. 2009. "Japanese Lower House Campaigns in Transition: Manifest Changes or Fleeting Fads?" Journal of East Asian Studies 9, 1: 121-149.

Krauss, Ellis S., and Robert J. Pekkanen. 2011. The Rise and Fall of Japan's LDP: Political Party Organizations as Historical Institutions. Ithaca, NY: Cornell University Press.

Lipscy, Phillip Y., and Ethan Scheiner. 2012. "Japan Under the DPJ: The Paradox of Political Change Without Policy Change." Journal of East Asian Studies 12, 3: 311-322. 
Maclachlan, Patricia L. 2006. "Storming the Castle: The Battle for Postal Reform in Japan." Social Science Japan Journal 9, 2: 1-18.

- 2011. The People's Post Office: The History and Politics of the Japanese Postal System, 1871-2010. Cambridge, MA: Harvard University Asia Center.

Medina, Luis Fernando, and Susan C. Stokes. 2007. "Monopoly and Monitoring: An Approach to Political Clientelism." In Patrons, Clients, and Policies: Patterns of Democratic Accountability and Political Competition, ed. Herbert Kitschelt and Steven I. Wilkinson, 68-83. Cambridge: Cambridge University Press.

Mori Hiroki. 2008. "Senkyo katei ni okeru rieki dantai no dōkō" [Interest group trends in the electoral process]. Döshisha högaku 330 (November): $45-77$.

- 2010. "Seiken kōtai zenya ni okeru dantai—seitō kankei no shosō" [Aspects of relations between groups and parties on the eve of regime change]. In Gendai shakai shüdan no seiji kinō: rieki dantai to shimin shakai [The political functions of contemporary social organizations: Interest groups and civil society], ed. Tsujinaka Yutaka and Mori Hiroki, 180-194. Tokyo: Bokutakusha.

Norgren, Christiana A. E. 2001. Abortion Before Birth Control: The Politics of Reproduction in Postwar Japan. Princeton, NJ: Princeton University Press.

Park, Gene. 2011. Spending Without Taxation: FILP and the Politics of Public Finance in Japan. Stanford, CA: Stanford University Press.

Pempel, T. J., and Keiichi Tsunekawa. 1979. "Corporatism Without Labor? The Japanese Anomaly." In Trends Toward Corporatist Intermediation, ed. Philippe C. Schmitter and Gerhard Lehmbruch, 231-270. Beverly Hills, CA: Sage.

Reed, Steven R. 2009. "Party Strategy or Candidate Strategy: How Does the LDP Run the Right Number of Candidates in Japan's Multi-Member Districts?" Party Politics 15, 3: 295-314.

Reed, Steven R., Ethan Scheiner, and Michael F. Thies. 2012. "The End of LDP Dominance and the Rise of Party-Oriented Politics in Japan. Journal of Japanese Studies 38, 2: 353-376.

Rosenbluth, Frances McCall, and Michael F. Thies. 2010. Japan Transformed: Political Change and Economic Restructuring. Ithaca, NY: Cornell University Press.

Schaede, Ulrike. 2000. Cooperative Capitalism: Self-Regulation, Trade Associations, and the Anti-Monopoly Law in Japan. Oxford: Oxford University Press.

Schattschneider, E. E. 1960. The Semisovereign People: A Realist's View of Democracy in America. New York: Holt, Rinehart, and Winston.

Scheiner, Ethan. 2006. Democracy Without Competition in Japan: Opposition Failure in a One-Party Dominant State. Cambridge: Cambridge University Press.

- 2012. "The Electoral System and Japan's Partial Transformation: Party System Consolidation Without Policy Realignment." Journal of East Asian Studies 12, 3: 351-379. 
Schlozman, Kay Lehman, Sidney Verba, and Henry E. Brady. 2012. The Unheavenly Chorus: Unequal Political Voice and the Broken Promise of American Democracy. Princeton, NJ: Princeton University Press.

Schmitter, Philippe C. 1979. "Still the Century of Corporatism?" In Trends Toward Corporatist Intermediation, ed. Philippe C. Schmitter and Gerhard Lehmbruch, 7-52. Beverly Hills, CA: Sage.

Shinoda, Tomohito. 2013. Contemporary Japanese Politics: Institutional Changes and Power Shifts. New York: Columbia University Press.

Steslicke, William E. 1973. Doctors in Politics: The Political Life of the Japan Medical Association. New York: Praeger.

Thies, Michael F. 2002. "Changing How the Japanese Vote: The Promise and Pitfalls of the 1994 Electoral Reform." In How Asia Votes, ed. John Fuh-sheng Hsieh and David Newman, 92-117. New York: Chatham House.

Uekami Takayoshi and Tsutsumi Hidenori. 2011. "Minshutō no keiseikatei, soshiki to seisaku" [The formation process, organization and policies of the DPJ]. In Minshuto no soshiki to seisaku [The organization and policies of the DPJ], ed. Uekami Takayoshi and Tsutsumi Hidenori, 1-28. Tokyo: Tōyō keiai shinpōsha.

Wada Yoshitaka. 1997. "Zenkoku tokutei yūbinkyokuchōkai" [The national commissioned postmasters association]. Foresight (February): 120-123.

Wang, Chin-Shou, and Charles Kurzman. 2007. "Dilemmas of Electoral Clientelism: Taiwan, 1993." International Political Science Review 28, 2: 225-245.

Woodall, Brian. 1996. Japan Under Construction: Corruption, Politics, and Public Works. Berkeley: University of California Press.

Yamaguchi Osamu. 1993. Tokutei yūbinkyoku: zenkoku tokuteikyoku chōkai no ayumi [The commissioned post office: A history of the postmasters associations]. Tokyo: Gyōsei. 